\title{
The Hippocampal Complex of Food-Storing Birds
}

\begin{tabular}{|l|l|l|}
\hline D.F. & David F. & Sherry \\
\hline A.L. & Anthony L. & Vaccarino \\
\hline K. & Karen & Buckenham \\
\hline R.S. & Rachel S. & Herz \\
\hline
\end{tabular}

Department of Psychology, University of Toronto, Ont., Canada

\section{Key Words}

Hippocampus

Hippocampal complex

Memory

Food storing

Hoarding

Caching

Birds

Passerines

\section{Abstract}

Three families of North American passerines - chickadees, nuthatches and jays - store food. Previous research has shown that memory for the spatial locations of caches is the principal mechanism of cache recovery. It has also been previously shown that the hippocampal complex (hippocampus and area parahippocampalis) plays an important role in memory for cache sites. The present study determined the volume of the hippocampal complex and the telencephalon in 3 food-storing families and in 10 non-food-storing families and subfamilies of passerines. The hippocampal complex is larger in food-storing birds than in non-food-storing birds. This difference is greater than expected from allometric relations among the hippocampal complex, telencephalon and body weight. Food-storing families are not more closely related to each other than they are to non-food-storing families and subfamilies, and the greater size of the hippocampal complex in food-storing birds is therefore the result of evolutionary convergence. Natural selection has led to a larger hippocampal complex in birds that rely on memory to recover spatially dispersed food caches.

\section{(C) 1989 S. Karger AG, Basel 0006-8977/89/0345-0308 S 2.75/0 Introduction}

Three families of North American passerines -chickadees (Paridae), nuthatches (Sittidae), and jays and crows (Corvidae) - store food in widely dispersed cache sites. An iiffividual bird can establish several hundred cache sites in a single day and several thousand in the course of a year. Each cache is in a novel spatial location, and cache sites are not re-used in the wild. Cached food may be retrieved after a few days or after many months, depending on the species. Food storing of this kind occurs in no other North American passerines. Shrikes (Laniidae) store food in a different way, impaling small numbers of prey at a few sites to assist in handling the prey rather than to establish a reserve of stored food $[1,2]$.

A number of studies have examined how food-storing birds recover their caches of food and have shown that memory for the spatial locations of caches is the

principal mechanism. Chickadees and their European counterparts, the tits, readily recall the locations of caches [3-8], as do a number of species of corvids [9-14]. These findings are reviewed in Sherry [15] and Balda et al. [16]. It can be shown that cache recovery accuracy is consistently greater than expected by chance and greater than expected from preferences to use particular kinds of cache sites. There is no evidence that birds mark their cache sites or use mnemonics based on the sequence of storing to relocate caches. Although magpies (PiGafbica) 
are able to $\mathrm{s}^{\wedge \wedge} \mathrm{J}$ Itffiaed food [17], cache recovery remains highly accurate in other species when they are prevented from smelling^stored food.

In mammals, the hippocampus plays an important role in memory and information processing. Two dominant theories of thefuncfi\&n of the hippocampus deal with the processing of spatial information $[18,19]$ and working memory [20], though a variety of

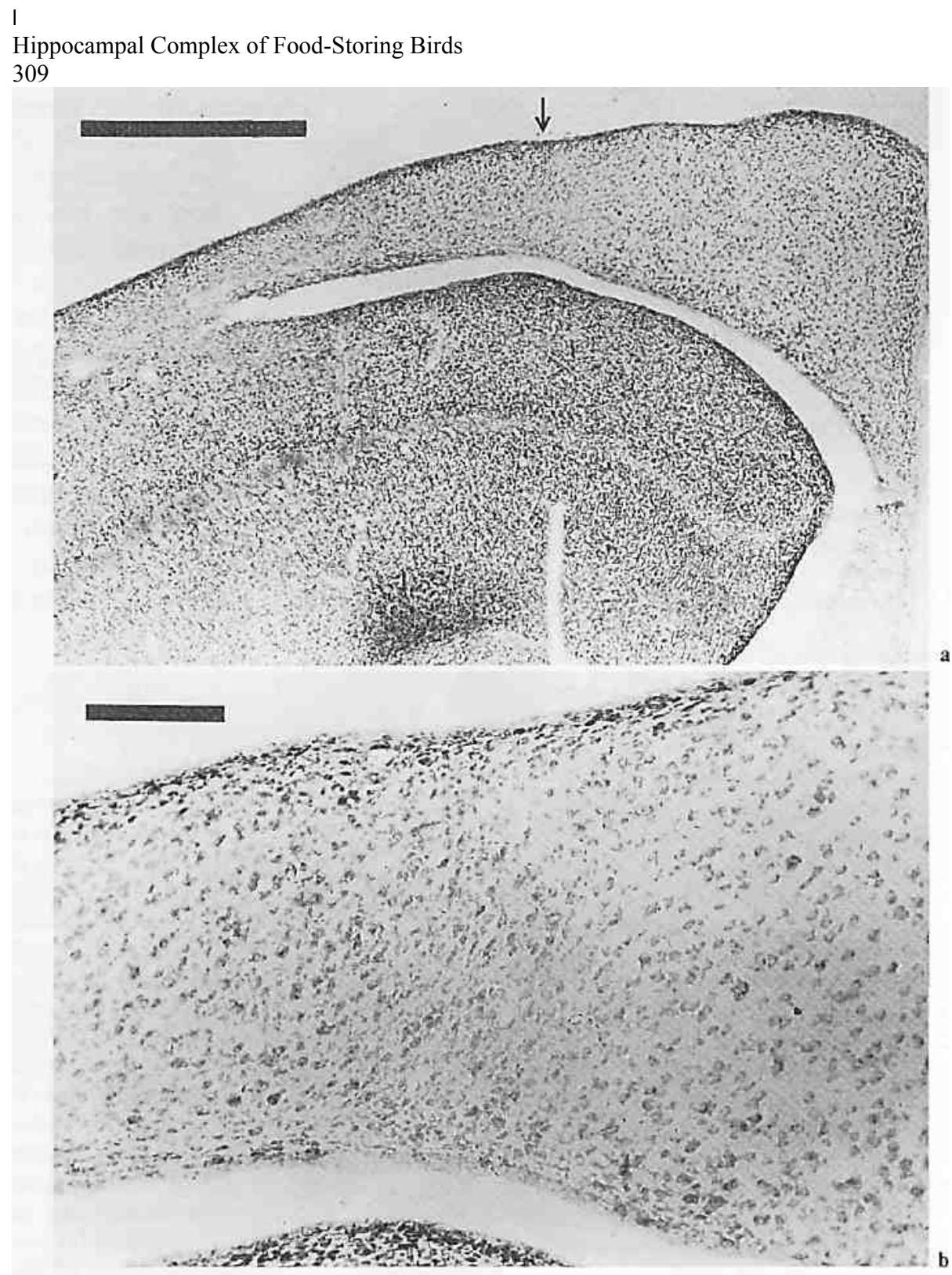


Fig. 1. Boundary used to define the lateral extent of the hippocampal complex. aJjsft Hp-APH of black-capped chickadee. Section at about the level of Section $b$ in figure!. Arrow indicates lateral margin. Scale bar $=1 \mathrm{~mm}$. b Enlargement of re-RnjSftindicated by arrow in a. Scale bar $=100$ urn.

other theoretical accounts have also been offered [e.g. 21]. It has been demonstratedChat the hippocampal complex of birds (hippocampus and area parahippo-campatts; Hp-APH) is homologous to the hippocampal formation of mammals, on the basis of ontogen-E|iS[22] and neuro-anatornl ${ }^{\wedge} \mathrm{S}$ similarities [23-27]. The detailed relation between structures within the hippocampal formation of mammals and those within the Hp-APH of birds, however, are not yet clear.

Lesions of the hippocampal complex disrupt cache recovery in black-capped chickadees (Parus amjcapil-lus) [28]. Damage to Hp-APH produces defMMtijai memory for spatial locations and deficits ${ }^{\wedge}$ 'working memory. Lesions of the hyperstriatum that include the hippocampus also disrupt cache recovery in a cor-vid food-storer, the Eurasian nutcracker (Nucifraga caryocatactes) [29]. In homing pigeons, lesions of Hp-APH impair orientation and recognition of the home loft $[30,31]$. The hippocampal complex of birds thus shares some func ${ }^{\wedge} n s$ with the homologous structure in mammalian brains.

Morphometric analysis of brains from a variety of passerines had previously indicated that there exist differences in the size of the Hp-APH between food-;storing and non-food-storing species [32]. The present

310

Sherry/Vaccarino/Buckenham/Herz

Table 1. Species and measured variables

$\mathrm{mm}-$

Body weight Hp-APH volume Telencephalon volume

Corvidae $^{1}$

Cyanocitta $M M$

bluejay

1

113.32

45.68

Paridae $^{1}$ 
Sitta canadensis

red-breasted $\mathrm{r}^{\wedge \wedge \wedge \wedge \wedge} \mathrm{H}$

1

11.5

7.52

Troglodytidae

Troglodytes aedon

hous ${ }^{\wedge} \mathrm{mren}$

2

10.2

3.84

Sylviinae

Regulus calendula

ruby-crowned kinglet

1

7.3

1.51

Turdinae

Turdus migratonushL

American robin

79.0

10.42

KGmidae

681.61

Dumetetta carolinensis grav'catb irc «

1

40.7

6.86

$\wedge^{\wedge}$ midae 
Sturnus vulgaris

European starling

1

96.5

17.80

Parulinae

Dendroica magnolia magnolia warbler

1

8.2

1.66

Dendroica coronata gjyellow-rumped warbler 1

12.4

2.41

158.82

Dendroica striata blackpoll warbler 1

11.9

2.60

175.74

Setophaga ruticilla

American redstart

1

7.2

0.99

89.16

Seiurusfaurocapillus ovenbird

1

16.9

3.67

Seiuruslnoveboracensis nothern waterthrus ${ }^{\wedge} \mathrm{M}$

1

19.6

1.51

Geoi]\$\$pis trichas

144.06 common yellowthroat 1

9.4

2.55

215.43

mean

12.2

2.20

CardinaUnae 
v ${ }^{*}$ feqmi ${ }^{\wedge \text { ii.s }}$ cardn $^{\wedge \wedge \wedge} \mathrm{H}$ northern $\operatorname{card}^{\wedge \wedge} \mathrm{M}$

1

44.0

16.48

695.46

PheuEticus ludomcianus rose-breas ${ }^{\wedge} \mathrm{S}$ grosbeak 1

43.2

3.99

mean

43.6

10.24

Emberizinae

Melospiza melodia

song sparrow

1

20.6

3.80

Melospiza georgiana swamp sparrow

1

18.1

3.96

Zonotrichia aWjEpllis

whittjgthroated sparrow

1

24.2

5.40

$\mathrm{jJw} /$ ico hyemalis dark-eyed junco

1

19.5

6.66

mean

20.6

4.96

Fringillidae 
Ca r duel is tristis

American goldfincnM

1

12.5

3.85

Passeridae

Passer domesticus $\wedge$

house spai $^{\wedge \wedge} \mathrm{M}$

3

25.32

6.99

Food-stopng fammesl

Hippocampal Complex of Food-Storing Birds

311 

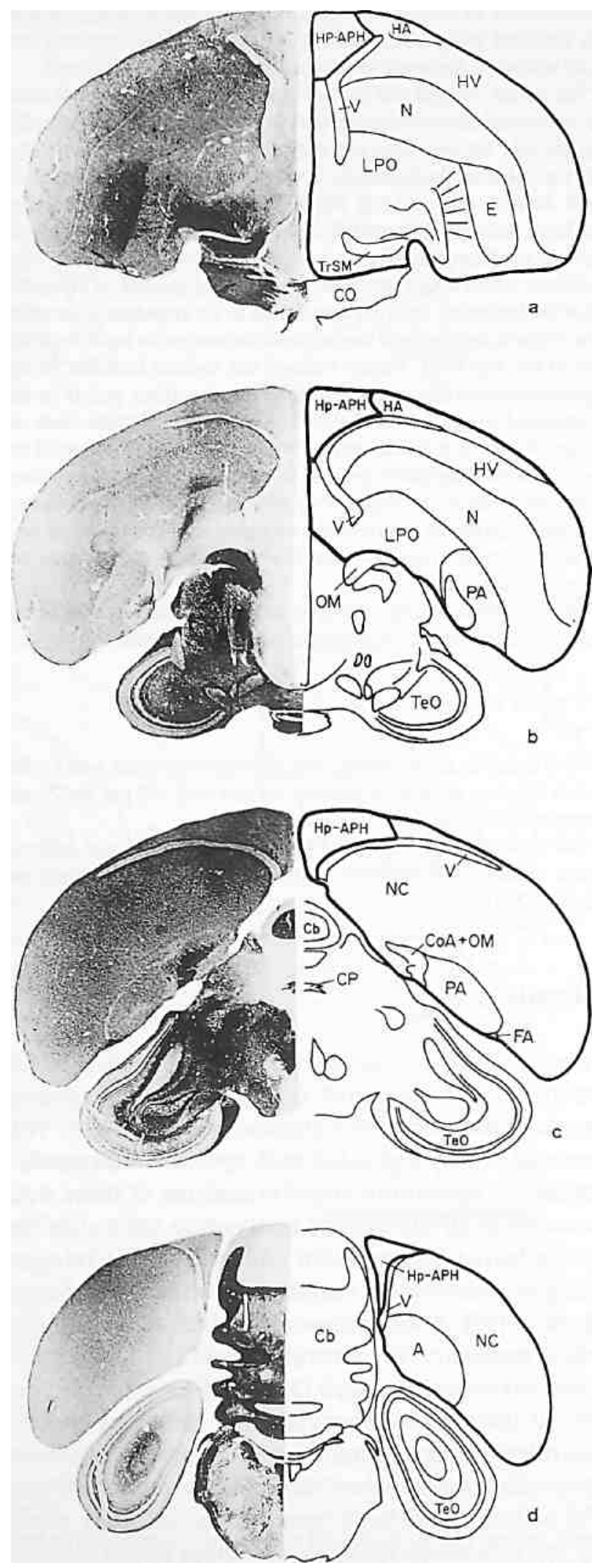

paper describes a comparative analysis of theteize of the hippocampal complex in 23 species of North American passerines drawn from the 3 food-storing families and from 10 non-food-sroring families and subfamilies. Results on food-storing and non-food-^roring European passerines are described elsewhere [33]. [ 
In the present study, the volume of the hippocampal complex and telencephalon were determined from serial sections. The relation of Hp-APH volume to body weight, telencephalon volume and caching behaviour was determined by multiple regression! Additional analyses were performed to examine the influence on Hp-APH volume of a number of other variables that might be expected to affect brain evolution: migratory behaviour, diet and social orga-Erzation.

\section{Materials and Methods}

Twenty-eight birds from 23 species in 13 passerine families and subfamilies were collected (table 1). Birds were collected under Canadian Wildlife Service permit at the Erindale campus of the TSSBji versity of Toronto and at the Long Point Bird Observatory on the north shore of Lake Erie. All procedures followed guidelines established by the Canadian Council on Animal Care. Body weight was recorded, the bird was anaesthetized with sodium pentobarbital (Nembutal, $7 \mathrm{u}, \mathrm{g} / \mathrm{g}$ ) and perfused with $0.9 \%$ physiological saline followed with $10 \%$ formalin. The brain was removed and placed in $10 \%$ sucrose formalin for $24 \mathrm{~h}$, followed by storage in 30\% sucrose formaliiruntil sectioning. Frozen sections were made in the coronal plane at either 25- or 40-u.m intervals and stained using Auletta stain for cells and fibres. Brains were mounted for sectioning to maintain, as far as possible, comparable section planes in different Species, although because the data of interest were volume estimates perfect alignment was not necessary. Every 6th section in the case ora5-u,m sections and every 4th section in the case of 40-jj.m sections was enlarged $15 \mathrm{x}$ using a Bausch \& Lomb slide enlarger, and outlines of the Hp-APH, telencephalon and other structures were traced. Sections were viewed by light microscope (Nikon Op-

Fig. 2. Hippocampal complex and telencephalon of black-capped chickadee. Regions included in hippocampal complex and telericepjialon are indicated with heavy outline. Sections a-d are ordered rostrocaudally. Scale bar $=5 \mathrm{~mm}$. A = Archistriatum; $\mathrm{Cb} »$ cerebellum; $\mathrm{CO}=$ chiasm opticum; CoA g comniissura anterior; CP g commissura posterior; DSV = decussatio supraoptica ven-trale; E 5 ectostriatum; FA = tractus fronto-archistriatalis; $\mathrm{HA}=$ hyperstriatum accessorium; $\mathrm{HV}=$ hyperstriatum ventrale; $\mathrm{LPO}=$ lobus parolfactorius; $\mathrm{N}=$ neostriatum; $\mathrm{NC}=$ neostriatum caudale; $\mathrm{OM}=$ tractus occipito-mesencephalicus; $\mathrm{PA}=$ paleostriatum augmentation; $\mathrm{Rt} \mathrm{g}$ nucleus rotundus; $\mathrm{TeO}=$ tectum opticum; TrSM tractusis'eptomesencephalicus; V = ventricle. [Nomenclature follows ref. 50 and 51.$]$

312

Sherry/Vaccar^ho/Buckenham/Herz

tiphot) at $10 \mathrm{x}$ to confirm and to add anatomical details. Tracings were digitized using a Numonics 2210 tablet, microcomputer and Jandel software. Accuracy of the tracing tablet was $+0.025 \mathrm{~mm}$. ,

The dorsal, ventral and medial extent of the hippocampal complex in coronal sections correspond to the surface of the brain.j $\mathrm{K}^{\wedge}$ ventricle and the midHiSe. respectively. The laterallplgctent of Hp-APH was taken as the boundary at which there is a marked increase in cell density, compared to Hp-APH, and a change in cell type from large neurons characteristic of Hp-APH to a mixture of both large and small neurons (fig. 1). Lateral to this boundary, cells show an oblique or cugang alignment, while on the medial or Hp-APH side of the boundary cells are distributed in no apparent alignment. These criteria can be used throughout the rostral to caudal occurrence of the Hp-APH. Figure 2 shows the regions included in the hippocampal complex and telencephalon at various points in the rostrocaudal extent of Hp-APH. The Hp-APH of passerines, in contrast to that of pigeons, retains a dorsomedial polmon with respect to the telencephalon even at its caudal limit, and in sections remains attached to the larger body of the telencephalon, as shown; in figure $2 \mathrm{~d}$. Staining, sectioning, enlarging and tracing were performed blind with regard to food storing, migration and other behaviour of each species.

The volume contained between successive sections was $\mathrm{ca}^{\wedge \wedge}$ lated using the formula for volume of a truncated $\operatorname{cor}^{\wedge} \mathrm{M}$

$\mathrm{V}=-\left(\mathrm{h},+\mathrm{Vh} 7-\mathrm{VhT}+\mathrm{h}_{2}\right)$

SnMhichh[ and $\mathrm{h}_{2}$ are the areas from successive ${ }^{\wedge}$ tions, and lis the interval between successive sections, in this'case 150 urn for $25-\mathrm{u}, \mathrm{m}$ sections and 160 urn for 40 -urn sections.

The relation between Hp-APH volume, body weight, telencephalon volume and behaviour was determined by multiple regression [34].

\section{Results}

Figure 3 shows sections through the Hp-APH for several food-storing and non-food-^roring species. Hippocampal complex volumes, telencephalon volumes and body weights for each species are presented in table 1. Logarithmic transformations of these data were used in all subsequent analyses to normalize the data for sEtistical treatment and because the relation among morphological variables isgexpected to be exponential [35]. With comparative data of this kind it is also necessary to control for non-independence among taxonomic groups [35S7]. For example, because of their evolutionary affinity the many species of warblers (table 1) should probajSy not be regarded as providing independent data on the relation of Hp-APH to brain and body weight. 
Instead $^{\wedge}$ mey $\mathrm{pi}^{\wedge} \mathrm{H}$ ably provide many replicatet ${ }^{\wedge}$ tances of the relation among these variables as it exists in warblers. We followed the method of Clutton-Brock and Harvey [35,

$36]$ to determine at what taxonomic level observati\&gl could be regarded as independent. AnaLrois of vartanceKor an unbalanced design with genus nested ${ }^{\wedge}$ nin subfamily and subfamily nested within family showed a significant effect for subfami ${ }^{\mathrm{TM}}[\log \mathrm{Hp}-\mathrm{APH}$ volume: $\mathrm{F}(3,6)-6.09, \mathrm{p}<0.05$; log telencephalon volume: $\mathrm{F}(3,6)=$ $11.00, \mathrm{p}<0.01$; $\log$ body weight: $\mathrm{F}(3,6)-16.08, \mathrm{p}<0.01$ ] and no significant effect for either genus or family. Subfamily was therefore chosen as the taxonomic level for all analyses, and mean values for subfamilies were calculated from all species in each subfamily. In cases where there is only a single subfamily represented in a family, that subfamily is givenpts family name in table 1. Taxonomy and nomenclature follow the American $\mathrm{Ojgj}^{\wedge}$ thologists' Union (AOU) check-list [38].

Multiple regression was used to examine the relation between the variable log Hp-APH volume and the three variables $\log$ body weight, $\log$ telencephalon volume and food-storing behaviour [34]. When variables were entered in the regression in a step ${ }^{\wedge} \mathrm{S}$ fashion, telencephalon volume accounte\&tfor a substantial proportion of the variance in Hp-APH volume $\left(\mathrm{r}^{2}=0.755\right)$ and was found to have a coefficient significantly greater than zero $[\mathrm{F}(1,11)=33.81, \mathrm{p}<0.01]$. This relation* between the hippocampal complex and the telencephalon shows that, as expected, birds with larger brains have a larger hippocampal complex. Body weight accounted for no additional variance in Hp-APH volume beyond that accounted for by telencephalon volume and did not have a coefficient sigjfcf||lntly different from zero. Food storing, in contrast, did account for additional variance in Hp-APH volume, raising the $\operatorname{proporl}^{\wedge} \mathrm{S}$ of variance accounted for $\left(\mathrm{r}^{2}=0.968\right)$ and was found to have a significantly non-zero coefficient $[\mathrm{F}(1,10) \mathrm{g} 67.73, \mathrm{p}<0.01]$. The regression of Hp-APH volume on telencephalon volume and foodstoring behaviour minimized Mallow's $C_{p}\left(C_{p} g\right.$ 2.32) compared to regressions on all possible subsets of variables and produced an overall regression significantly greater than zero $[\mathrm{F}(2,10)=153.3, \mathrm{p}<0.01]$.

The relWon of Hp-APH volume to body weight and telencephalon volume is illustrated in figure 4. It can be seen that for each food-stcaffrig family the hippocampal complex is larger than expected from the ${ }^{\wedge}$ Mion between hippocampal complex volume and telencephalon volume. The same is true for the relation between hippocampal complex vqmme and body weight. The relation between telencggnalon volume

Hippocampal Complex of Food-Storing Birds $\mathrm{BIB}$

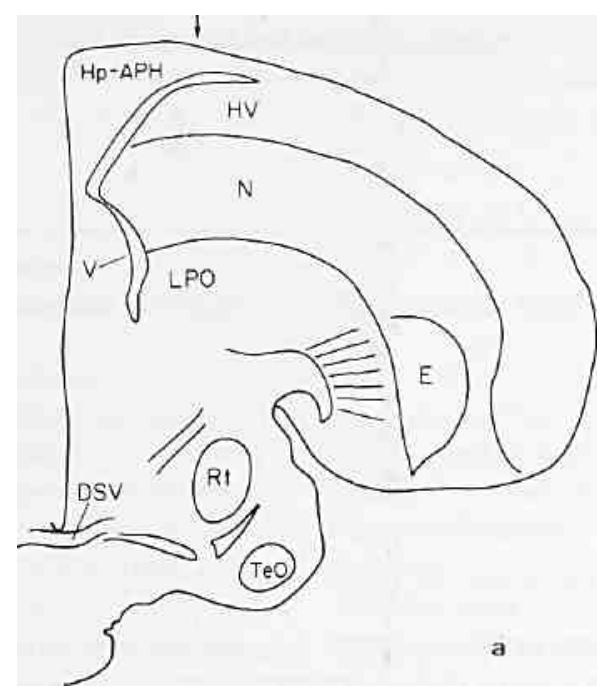



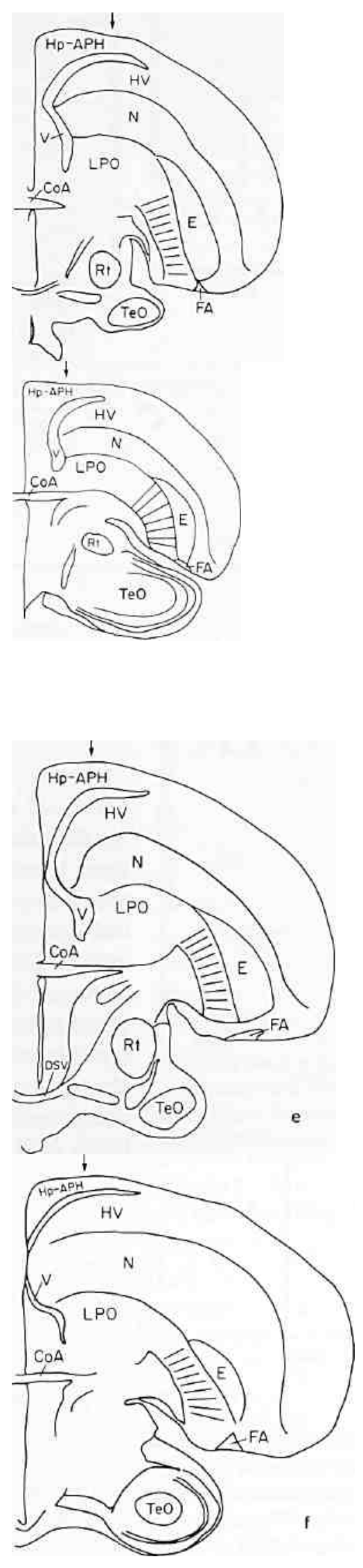

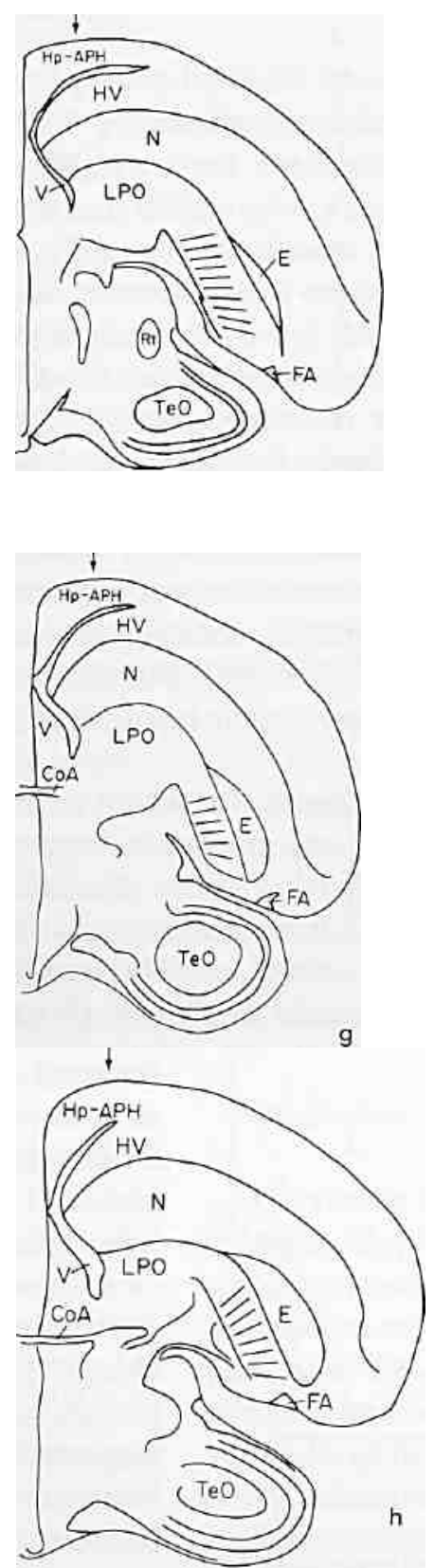

Fig. 3. oxon $^{\wedge}$ EecUons through the hippocampal complex at the level of the anterior commissure for 3 food-storing species, blue jay $\left({ }^{\mathrm{a}}\right)>$ blja ${ }^{\wedge}$ capped chickadee (b) $\underline{\operatorname{arTa}}$ red-breasted nutKaTpQHcY, and 5 non-food-storing species, house wren (d), Northern cardinal (e), rose$\wedge^{\wedge} \&$ ted grosbeak (f), darkr ${ }^{\wedge}$ yed junco $(\mathrm{g})$ and house sparrow $(\mathrm{h})$. Arrow indicates lateral margin of Hp-APH. Scale bar $=5 \mathrm{~mm}$. Abbreviations as in figure 2.

314

Sherry/Vaccarino/Buckenham/Herz 
A A A

0

20

50

BODY WEIGHT (grams)

100

A

A

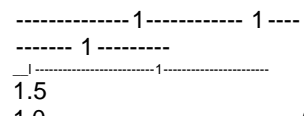

$\begin{array}{lllll}1.0 & -0.5 & 0.0 & 0.5 & 1.0\end{array}$

HP - APH BY BODY WEIGHT RESIDUAL

Fig. 5. Residuals of the regression between Hp-APH volume and telencephalon volume plotted against residuals of the regression between Hp-APH volume and body weight. $\boldsymbol{\Delta}$ = Food-storing subfamilies: A = non-food-storine suCMnmiesiH

50

A

A
10 


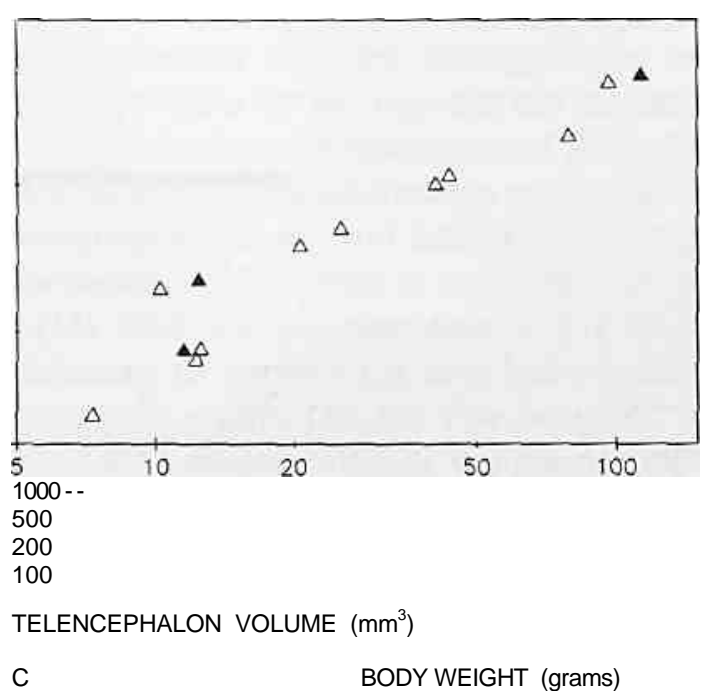

Fig. 4. Regions between. Hp-APH volume and body weight (a), Hp-APH volume and telencephalon volume (b) and telencephalon volume and body weigh $\underline{\wedge} \mathrm{cjBi},=$ Food-rStojinE subfamilies; $\mathrm{A}=$ non-food-storing subfamilies. All variables are plotted on logarithmic axes.

and body weight is the same for food-storing birds as it is for other birds. The relation between Hp-APH volume, telencephalon volume and body weight can be seen more clearly in figure 5, which plots the residuals from regressions fitted to the data shown in figures $4 a$ and $b$. These residuals show the difference between observed $\mathrm{Hp}$-APH volume for a subfamily and that predicted from the regression calculated for all subfamilies. Residuals for non-food-storing families cluster near zero. Residuals for the 3 food-storing families are all positive, and are the largest $\operatorname{resid}^{\wedge \wedge} \mathrm{a}$ in the data set.

$\mathrm{Mi}^{\wedge}$ ple regres${ }^{\wedge} \mathrm{n}$ was repeated, replacing food-storing beha^\&ur with either migratory behav ${ }^{\wedge \wedge} \mathrm{a}$ (migrant - nonmigrant), diet (omnivore - special ${ }^{\wedge \mathrm{TM}}$ or social organization (solitary - sociSS; but none of these variables accounted for significant variation in Hp-APH volume in addition to that accounted for by telencephalon volume. A subset of migratory spectesv for which estimates of th^mstance traveled during migration were available [39], was analyzed further (table 2). Telei^ $\mathrm{i}^{\wedge}$ phalon vc5EETme accounted for substantial variation in hippocampal complex volume $\left(\mathrm{r}^{2} \mathrm{~g}=0.911\right)$ and had a coeffieientfsignificant ${ }^{\wedge}$ greater than zero $[\mathrm{F}(1,6)=62.05, \mathrm{p}<0.01]$, but no additional variation was accounted for by either body weight or the $\mathrm{j}^{\wedge} \mathrm{jance}$ traveled during migration. The $\mathrm{rel}^{\wedge} \mathrm{j}$ Sns between Hp-APH volume and migratory distance in these biSls are shown in figure 6 . 


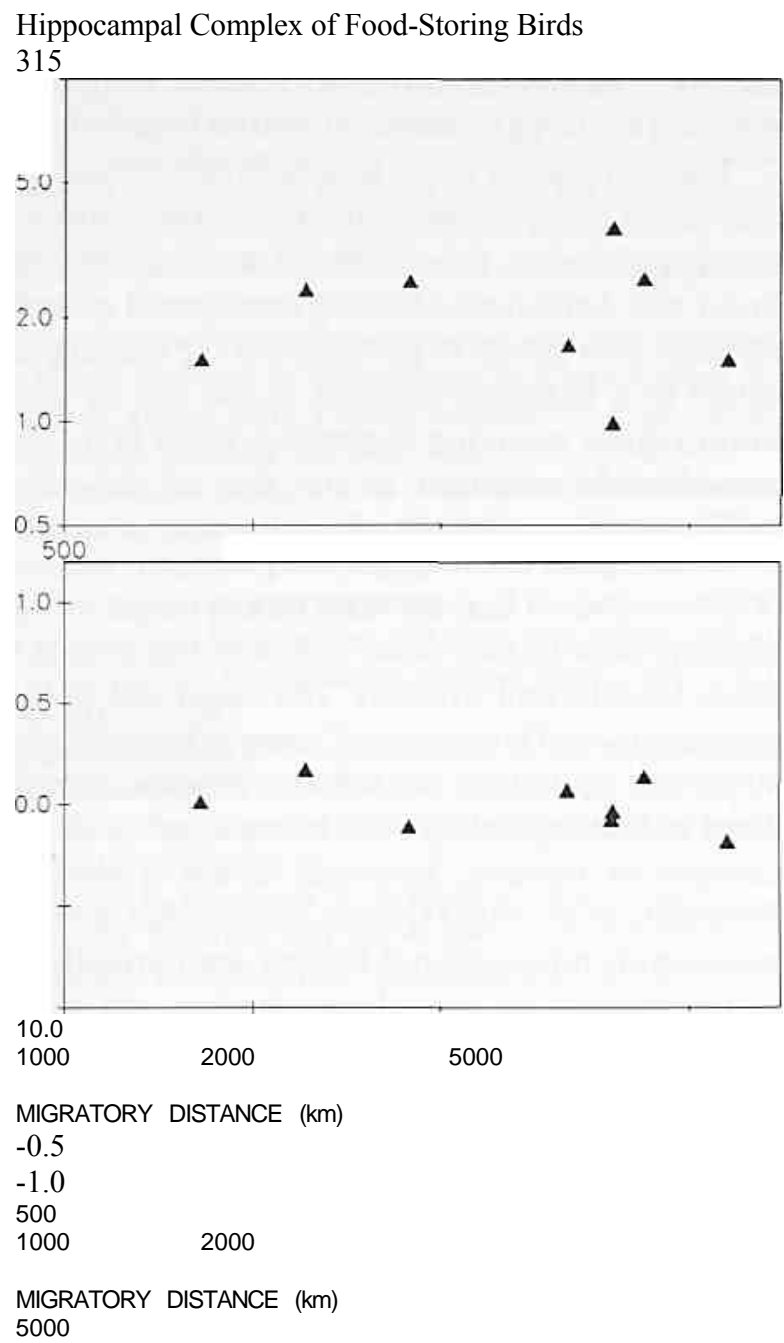

Table 2. Migrants and migration distance

Migration

-'Siistance 
Dendroica magnolia

magnolia warbler

3,199

Dendroica coronata

yellow-rumoed warbler

1,211

Dendroica striata

blackpoll warbler

4,235

Setophaga ruiicilla

American redstart

3,767

Seiurus aurocapillus

ovenbird

3,784

Seiurus novebracensis

northern waterthrush

5,768

GeoffilypisltrAchas

coirfmjon yellowthroat

1,782

Distances are means from figures 10 and 11 of Keast [39], which

SIDL

give approximate distant

between centres of breeding

and winter-

ing ranges.

M.ON

Fig. 6. a Relation between Hp-APH volume and migratory distance for the 8 migratory species shown in table 2 . Migratory distances are from Keast [39]. Both, variables are plotted on logarithmic axes, b Residuals of the regression between Hp-APH volume and telencephalon volume for 8 migratory species plotted against migratory distance. Distance axis is logarithmic.

Discussion

The results show that food-storing passerines have a larger hippocampal complex than do non-food-storing passerines. This effect is in addition to the expected size relations between $>$ the hippocampal complex and the brain and between the hippocampal complex and body weight. The 3 food-storing families with a large hippocampal complex are not closely related, indicating that the changes in hippocampal size are the result of evolutionary convergence. The details of Hp-APH straerare were notjexamined in the present study. Thus, adaptive modification of the hippocampal complex may differ in the 3 food-storing families. There may be more than one way in which

A final possibility is that, despite the statistical independence among subfamilies, food-storing birds di£fer from other passerines for reasons that are purely phylogenetic. That is, birds in the families Paridae, Sittidae and Corvidae may be similar in Hp-APH size, and different from other passerines, because the 3 families are closely related. The fact that they stare food too may be just a further similarity. Paridae, Sittidae and Corvidae, however, are not more closely related to each other than they are to other passerine families and subfamilies. The AOU 
check-list [38Whe arbiter of North American avian taxonomy, places all of the families analyzed in the passerine suborder Passeres. Families within Passeres are not grouped into higher-order categorS, such as superfamilies. Sibley and Ahlquist [40] have presented a phylogeny and classification of passerines based on DNA hybridization. Their results differ somewhat from the AOU [38] classification. They do not, however, indicate that Paridae, Sittidae and Corvidae are more closely related to each other than they are to other passerines. Paridae and SiraoaSare placed in the raiBorder Muscicapae and Corvidae in the par-vorder Corvi. Within Museicapae the family regarded as closest to the Sittidae is the Troglodytidae, and members of the Paridae are regarded as more closely related to the kinglets [family Regulidae in ref. 40; subfamily Sylginae in ref. 38] than to members of the EEdae.

316

Sherry/Vaccarino/Buckenham/Herz

Hp-APH can be modified to achieve long-duration memory for large numbers of spatial locafiSns.

There are many casein which differences among species of birds in the structure of the brain can be clearly related to the effects of natural selection on brain and behaviour. Among scolopacid shorebim ${ }^{\wedge}$ reliance on a sens ${ }^{\mathrm{TM} \wedge} \mathrm{e}$ probing bill for feeding has resulted in a dramatic increase in the size of the fore-brain region receiving trigeminal input [41], TherejSj! considerable variation in the size of the olfactory bulbs in birds, and these can be related to reliance on olfaction [42]. Differences in size of the song repertoire are correlated with differences in size of the song control nuclei $[43,44]$.

With regard to the hippocampus, Rehkamper et al. [45] have shown that the structuxe is larger in homing pigeonS! than in two other non-homing breeds of pigeon, fantails and strassers. The larger size of the hippocampus, and larger size of some other telenceph ${ }^{\wedge} \mathrm{S}$ structures including the olfactory bulbs, may be related to homing ability. The role played by the hippocampus in homing, however, is not a simple one. Bingman et al. [30, 31] have shown that homing pigeons with hippocampal lesions are correctly homeward oriented at the release site but are slower to reach home than controls and encounterKifficulljS when within sight of the home loft. Nonetheless, the results of Rehkamper et al. [45] show that selection by man can produce differences in hippocampal size that correlate with orientation abilities. Artiflcmliselection has also produced differences in the fine structure of the hippocampal formation in mammals. For example, strains of mice which show greater habituation to a novel environment have larger mossy fiber termination fields [46].

In mammals, the hippocampal formation increases in size from the insectivores to the prosimlans and from the prosimians to the higher primates, after allowing for differences in body size [47], but this general trend is difficult to relate to specific selective pressures. Other neuro-anatomjcal structures in mammals, however, are clearly correlated with ecological and social variables. Indices of cerebral cortex size are correlated in prosimians with troop size, in New World monkeys with size of the troop home range and in Old World monkeys with size of the individual home range [48], suggest ${ }^{\wedge \wedge}$ at different selecnBa ${ }^{\wedge \wedge \wedge} \mathrm{Ss}$ have influe ${ }^{\wedge} \mathrm{Sd}$ the evSffiion of the cortex in different primate taxa. Armst ${ }^{\wedge} \mathrm{mg}$ et al. [49] have shown that the anterior thalamic nuclei are relatively larger in primate $^{\wedge}$ gith siggj)b-male social groups than in primates with multi-mafSocial groups.

The greater size of the hippocampus in food-storing birds provides a clear case in which natural selection has modified a brain region involved in a cognitive component of behaviour. The increased size of the hippocampus in 3 unrelated families of food-storing passerines indicates that natural selection favouring food storing has resulted in modification of the [OEain regSi that plays a central role in memory for cache sites. Although the discussion has,stressed that the observed differences are the result of natural selection, this does not discount the possibility that indi-^ $\mathrm{v} \&$ lual experience in storing and retrieving food may play a role in the development of thisraize difference in the hippocamp ${ }^{\wedge} \mathrm{M}$

\section{Acknowledgments}

We would like to thank Vern Bingman, Jon ErK\&sen, Allen Keast, John Krebs, Michael Leon, Hugh Perry, John Yeomans and jEranco Vaccanno for their many helpfuJE\&rnments and sugges- ${ }^{\wedge \wedge}$. We alsolthank George Wallace and the Long Point Bird Observatory for their invaluable help in collecting birds, Alasdair Houston who kiruuy provided the formula for calculating volumes from section areas and Martin Daly who suggested the analysis of migrant warblers. 
1 Cade TJ: Ecological and behavioral aspects of predation by the northern shrike. Living Bird 1967;6:43-86.

2 Gronlund S, Itamies J, Mikkola H: On the food and feeding habltsrof the great grey shrike Lannis, excubwmin Finland. Or-

KusFenn 1970;47:167-171.

3 Baker MC, Stone E, Baker AEM, et al: Evidence agafnwobser-vational learning in storage and recovery of seeds by black-capped chickadees. Auk 1988;105:492-497.

4 Sherry DF: Food storage, memory and marsh tits. Anim Behav 198^ffl:631-633.

5 Sherry DF: Food storage by black-capped chickadees: Memory for the location and contents of $\wedge^{\wedge}$ es. Anim Behav 1984;32: 451-464.

6 Sherry DF, Krebs JR, Cowie RJ: Memory for the location of stored food in marsh tits. Anim Behav 1981;29:1260-1266.

7 Sheffleworth SJ, Krebs JR: How marsh tits find their hoards: The roles of site preference and spatial memory. J Exp Psychol [Anim Behav] 1982;8:354-375.

8 ShefflEworth SJ, Krebs JR: Stored and encountered seeds: A comrjarison of two spatial memory tasks in marsh tits and chickadees ${ }^{\wedge}$ Exp Psychol [Anim Behav] 1986; 12:248-257.

9 Balda RP, Kamil AC: A compai^rae study of cache recovery by three corvid species. Anim Behav 1989;38:486-495.

10 Bunch KG, Tomback DF: Bolus rec^Kry by gray jays: An experimental analysis. Anim Behav 1986;34:754-762.

Hippocampal Complex of Food-Storing Birds

317

11 James PC, Verbeek NAM: The food storage behaviour of the northwestern crow. Behaviour 1983;85:276-291.

12 Kamil AC, Balda RP: Cache recovery and spatial memory in Clark's njTTcrackers (Nuafraga columbiana). J Exp Psychol [Anim Behav] 1985;11:95-111.

13 Tomback DF: How nutcrackers find their seed stores. Condor 1980;82:10-19.

14 Vander Wall SB: An experimental analysis of cache recovery in Clark's nutcracker. Anim Behav 1982;30:84-94.

15 Sherry DF: Food storage by birds and mammals. Adv Study Behav 1985;15:153-188.

16 Balda RP, Bunch KG, Kamil AC, et al: Cache site memory in birds; in Kamil AC, JCrebs JR, Pulliam HR (eds): Foraging Behavior. New York, Plenum Press, 1987, pp 645-666.

17 BuiSn D, Nuechterlein GL: Experiments on olfactory detection of food caches by black-billed magpies. Condor 1985;87: 92-95.

18 O'Keefe J, Nadel L: The Hippocampus as a Cognitive Map. Oxford, Clarendon Press, 1978.

19 Morris RGM, Garrud P, Rawlins JNP, et al: Place navigation impaired in rats with hippocampal lesions. Nature 1982;297; 681-683.

20 Olton DS, Becker JT, Handelmann GE: Hippocampus, space, and memory. Behav Brain Sci 1979;2:313-322.

21 Rawlins JNP: Associations across time: The hippocampus as a temporary memory store. Behav Brain-Sd, 1985;8:479-496.

22jCallen B: Embryogenesis of brainfnuclei injthe chick telencephalon. Ergeb Anat Entwj^lungsgesch 1962;36:62-82.

23 Ari.ens*Kappers CU, Huber GC, Crosby EC: The Comparative Anatomy of the Nervous System of Vertebrates, Including Man. New York, Macmillan, 1936, vol $1+2$.

24 "Casini G, Bingman VP, Bagnoli P: Connections of the pigeon dorsomedial fprgt^ ${ }^{\wedge}$ studied with WGA-HRP and ${ }^{3} \mathrm{H}-$ pro-line. J Comp Neurol 1986;245:454-470.

25 Beriowitz LI, Karten HJ: The tractus infundibuli and other af-ferents to the parahippocampal region of the pigeon. Brain Res 1976;102:174-180.

26 Craigie EH: Studies on the brain of the kiwi (Apteryx australis). J Comp Neurol 1930;49:223-357.

$27 \mathrm{Kr}^{\wedge}$ miak PF, Siegel AiEfferent connections of the hippocampus and adjacent regions in the pigeon. Brain Behav Evol 1978;15:372388.

28 Sherry DF, Vaccarino AL: Hippocampus and memory for food caches in black-capped chickadees. Behav Neurosci 1989; 103: 308318.

29 Krushinskaya NL: Some complex forms of feeding behaS ${ }^{\wedge} \wedge \mathrm{H}$ of nut-cracker Nucifragwtcaryocatactes, after removal of old cortex. Zh Evol Biokhim Fiziol 1966;2:563-568.

30 Bingman VP, loale P, Casini G, et al: Dorsomedial forebrain ablations and home loft association behavior' in homing pigeons. Brain Behav Evol 1985;26:1-9.

31 Bingman VP, loale P, Casini G, etal: Impaired retention of pre-opeTanyely acquired spatial reference memory in homing pigeons following hippocampal ablation. Behav Brain Res 1987; 24:146-156.

32 Sherry DF, Vaccarino AL, Buckenham K, et al: Hippocampal size in food-storing birds. Soc Neurosci Abstr 1988;14:235.

33 Krebs JR, Sherry DF, Healy SD, et al: Hippocampal specialization of food-storing birds. Proc Natl Acad Sci USA 1989;86: 1388-1392.

34 Morrison DF: Applied Linear Statistical Methods. Englewood Cliffs, Prentice-Hall, 1983.

35 Clutton-Brock TH, Harvey PH: Comparative approaches to investigating adaptation; in Krebs JR, Davies NB (eds): Behavioural Ecology, ed 2. Sunderland, Sinauer, 1984, pp7-29.

36 Clutton-Brock TH, Harvey PH: Primate ecology and social organization. J Zool (Lond) 1977;183:1-39.

37 Harvey PH, Mace GM: Comparisons between taxa and adaptive trends: Problems of methodology; in King's College So-ciobiology Group (eds): Current Problems in Sociobiology. Cambridge, Cambridge UnSersity Press, 1982, pp 343-361.

38 American Ornithologists' UnHh: Check-list of North American Birds, ed 6. Lawrence, American Ornithologists' Union, 1983.

39 Keast A: Spatial relationships between migratory parulid warblers and their ecological counterparts in the neotropics ${ }^{\wedge} \mathrm{H}$ Keast $\mathrm{A}$, Morton ES (eds): Migrant Birds in the Neotropics. Washington, Smithsonian Insfiffition Press, 1980, pp 109-130.

40 Sibley CG, Ahlquist JE: The phylogeny and classification of the passerine birds, based on comparisons of the genetic material, DNA; in Ilyichev VD, Gavrilov VM (eds): Acta XVIII Congres-sus Internationalis Ornitholo^E. Moscow, Nauk\%S1985, vol 1, pp 83-121.

41 Pettigrew JD, Frost BJ: A tactile fovea in the Scolopacidae? Brain Behav Evol 1985;26:185-195.

42 Bang BG, Cobb S: The size of the olfactory bulb in 108 species of birds. Auk 1968;85:55-61. 
43 Nottebohm F, KasparSa S, Pandazis C: Bra^Kpace for a learned task. Brain Res 1981;213:99-109.

44 Canady RA, Kroodsma DE, Nottebohm F: Population differences in complexity of a learned skill are correlated with the brain space involved. ProcMSTatl Acad Sci USA 1984;81: 6232-6234.

45 Rehkamper G, Haase E, Frahm HD: ATHpmetric comparison of brain weight and brain structure volurn^ $\mathrm{E}^{\wedge} \mathrm{Hfferent}$ breeds of the domestic pigeon, Columba livia f.d. (fantail^Eoming pigeons, strassers). Brain Behav^Bol 1988;31:141-149.

46 Crusio WE, Schwegler H: Hippocampal mossy fiber distribution covaries with open-field hab ${ }^{\wedge}$ tion in the mouse. Behav Brain Res 1987;26:153-158.

47 Stephan H, Manolescu J: Comparative ${ }^{\wedge}$ Sestigations on hippocampus in insectivores and primates. Z Mikrosk Anat Forsch 1980;94:1025-1050.

48 Sawaguchl T: Correlations of cerebral indices for 'extra' cortical parts and ecological variables in primates ${ }^{\wedge} \mathrm{ffiram}$ Behav Evol 1988;32:129-140.

49 Armstrong E, Clarke MR, Hill EM: Relative size of the anterior thalamic nuclei differentiates anthropoids by social system. Brain Behav Evol 1987;30:263-271.

50 Karten HJ, Hodos W: A Stereotaxic Atlas of the Brain of the Pigeon (Columba livia). Baltimore, Hopkins University Press, 1967.

Stokes TM

Leonard CM

Nottebohm F: The telencephalon

di-encephalon

and mesencephalon of the canary

Serinus can ${ }^{\wedge} \mathrm{M}$ in stereotaxic coordinates. J Comp Neurol 1974;156:337-374. 